\title{
Resistant Plasmid Profile Analysis of Shigella spp Isolated from Stool Samples of School Children from Selected Communities in Odeda Local Government, Ogun State
}

\author{
Ajayi Olufunke ${ }^{1, *}$, Akinrotoye Kehinde Peter ${ }^{1}$, Akinduti Paul Akinniyi ${ }^{2}$ \\ ${ }^{1}$ Department of Microbiology, College of Biosciences, Federal University of Agriculture, Abeokuta, Nigeria \\ ${ }^{2}$ Department of Biological Sciences, College of Science and Technology, Covenant University, Ota, Nigeria
}

\section{Email address:}

funkeajayi13@gmail.com (A. Olufunke)

*Corresponding author.

\section{To cite this article:}

Ajayi Olufunke, Akinrotoye Kehinde Peter, Akinduti Paul Akinniyi. Resistant Plasmid Profile Analysis of Shigella spp isolated from stool samples of School Children from Selected Communities in Odeda Local Government, Ogun State. International Journal of Microbiology and Biotechnology. Vol. 4, No. 2, 2019, pp. 49-54. doi: 10.11648/j.ijmb.20190402.14

Received: May 23, 2019; Accepted: June 20, 2019; Published: July 10, 2019

\begin{abstract}
Shigellosis is a worldwide health concern especially in developing countries with poor sanitation, lack of personal hygiene and use of contaminated water supplies especially for young children. The emergence of multidrug-resistant Shigella strains incidence imply that shigellosis is an unsolved global health problem causing diarrhoea. This study therefore was carried out to determine the resistant plasmids of multidrug resistant serotypes of Shigella species isolated from stool samples of school children among selected communities in Odeda Local government with their biodata. A total of 10 Shigella spp isolates were obtained from stool samples collected from school children. Antibiotics susceptibility was performed and multidrug resistant isolates were selected for plasmid profiling. Plasmid profiling of multi-drug resistant Shigella isolates was done by alkaline lysis method. Molecular characterization for identification of the bacterial isolates was carried out using 16S rRNA gene sequencing method. Data obtained were analyzed using One-way Analysis of Variance (ANOVA). Somatic serotyping characterized the isolates to be Shigella flexneri (2.02\%), Shigella boydii $(1.2 \%)$ and Shigella sonnei $(0.81 \%)$. Plasmid profile analysis showed detectable plasmids with estimated sizes between 100bp to $1200 \mathrm{bp}$. Genomic characterization revealed the isolates belonging to Shigella sonnei strain M-X2D, Shigella flexneri strain MHW4.1 and Shigella boydii strain 3052-94. This study confirmed the emergence of multidrug resistant R-plasmids among Shigella spp causing diarrhoea amongst school children in Abeokuta environs, Nigeria.
\end{abstract}

Keywords: Antimicrobial Resistance, Shigella spp, Resistant Plasmids, Diarrhoea

\section{Introduction}

Shigellosis is a worldwide health concern especially in developing countries with poor sanitation, lack of personal hygiene and use of contaminated water supplies [1]. Malnutrition and the lack of appropriate medical intervention contribute to the high mortality rate, especially for young children. Despite global success in the reduction of all cause and diarrhoea-specific mortality in the past 30 years, diarrhoea remains the second leading cause of death due to infections among children fewer than five years of age worldwide [2]. It is estimated that diarrhoea accounted for $9.9 \%$ of the 6.9 million deaths among children under 5 in
$2011[3,4]$, and it has been reported that the prevalence rate of diarrhoea in Nigeria is $18.8 \%$; which is a menace in subSahara Africa [5].

The U.S. Centers for Disease Control and Prevention [6-8] has described antibiotic resistance as "one of the world's most pressing health problems", because "the number of bacteria resistant to antibiotics has increased in the last decade and many bacterial infections are becoming resistant to the most commonly prescribed antibiotic treatments [9]. The emergence of multidrug-resistant Shigella stains and a continuous high disease incidence imply that shigellosis is an 
unsolved global health problem [1]. Since it is an acute intestinal infection, the symptoms can range from mild watery diarrhoea to severe inflammatory bacillary dysentery characterized by strong abdominal cramps, fever, and stools containing blood and mucus.

Multiple drug resistance isolates causing diarrhoea has serious implications for the empiric therapy against pathogenic isolates and for the possible co-selection of antimicrobial resistant mediated by multi-drug resistant Plasmids. Shigella spp from clinical isolates are known to harbor plasmids of different molecular sizes; it has been widely reported that bacteria harbor antibiotic resistant genes which can be horizontally transferred to other bacteria. The progressive increase in antibiotic resistance among enteric pathogens in developing countries has been reported [10] which might be due to environmental factors, geographic differences or different patterns of antibiotic usage [11].

In Nigeria, though cases of Shigellosis (bacillary dysentery) due to Shigella species have been reported, to this very moment, there are few reports in Africa and Nigeria on molecular characterization of Shigella among school children with Shigellosis (bacillary dysentery) especially within rural and crowded communities. Therefore, it is imperative to to determine the resistant plasmids of multidrug resistant serotypes of Shigella species isolated from stool samples of school children among selected communities in Odeda Local government with their biodata, and its genetic characteristics.

\section{Methodology}

\subsection{Sample Collection}

A total of 248 stool samples were collected from the pupils. The samples were collected into sterile, transparent, wide mouthed bottles. The name, age and sex of the pupils were properly labeled on the universal bottles. After collection, the samples were transported to the laboratory using ice packs as transport medium and processing was done within 2 hours of collection. The pupils' biodata was obtained by administering a semi- structured questionnaire.

Ethical clearance for the study was obtained from both State Ministry for Health \& Education; Ogun State (Ref No: PL19/VOLIV/18) and was cleared by the Ethical Review Committee from College of Biosciences (COLBIOS), FUNAAB.

\subsection{Microbiological Analysis}

Stool samples were cultured within one hour of collection on to MacConkey agar, SSA agar, and Blood agar which were incubated aerobically overnight at $37^{\circ} \mathrm{C}$. Isolates were identified morphologically using the characteristics (size, shape, edge, and texture, degree of opacity, elevation and color) of each colony as described by Fawole and Osho, [12].

\subsection{Biochemical Test}

oxidation-fermentation tests, catalase, oxidase activity tests, Indole test, Gram's Stain, Methyl Red test, Voges
Proskauer test, Citrate utilization test, Triple sugar iron test, Coagulase test, was carried out according to Cheesbrough, [13].

\subsection{Antibiotics Susceptibility Test}

Antibiotic sensitivity test was carried out on all the bacterial isolates using disc diffusion technique according to Clinical and Laboratory Standards Institute, [14]. Mueller Hinton's agar plates were inoculated with the standardized inoculums of the overnight pure bacteria culture. After inoculation, appropriate Gram negative antibiotic sensitivity discs were placed aseptically and incubated at $37^{\circ} \mathrm{C}$ for 24 hours; after incubation, the diameter of the zone of inhibition were measured and compared with zone diameter interpretative chart by Clinical and Laboratory Standard Institute, [14]. Ten different antibiotics with different disc concentration such as Gentamycin (GEN) $10 \mu \mathrm{g} / \mathrm{disc}$, Ceftriaxone (CRO) 30 $\mu \mathrm{g} / \mathrm{disc}$, Cotrimoxazole (COT) $25 \mu \mathrm{g} /$ disc, Tetracycline (TET) $30 \mu \mathrm{g} /$ disc, Ciprofloxacin (CPX) $10 \mu \mathrm{g} / \mathrm{disc}$, Augmentin (AUG) $30 \mu \mathrm{g} / \mathrm{disc}$, Amoxicillin (AMX) $25 \mu \mathrm{g} /$ disc, Ofloxacin (OFL) $5 \mu \mathrm{g} /$ disc, Pefloxacin (PFX) $5 \mu \mathrm{g} /$ disc, Nitrofurantoin (NIT) $20 \mu \mathrm{g} /$ disc were used in this study.

\subsection{Serological Analysis for Shigella}

Isolates biochemically identified as Shigella were subjected to slide and tube agglutination test using polyvalent and monospecific somatic antisera according to the instruction of the manufacturer. The overnight pure culture of the different Shigella isolates was emulsified in a drop of $0.85 \%$ saline and mixed to form a smooth suspension on a clean dry tile. A drop of antisera was added to each suspension and mixed. The suspension was spread to cover the reaction area and rocked for one minute. Agglutination indicates positive reaction while no agglutination indicates negative reaction.

\subsection{Plasmid Profiling}

\subsubsection{Plasmid DNA Extraction}

Pure bacterial isolates were inoculated on Muller Hinton agar and incubated overnight. The grown culture was transferred into $1.5 \mathrm{ml}$ micro centrifuge tube containing phosphate buffer saline (PBS) and centrifuged at 10,000 rpm for 30 seconds. The supernatant was decanted and the pellet cells were suspended in $200 \mu$ l of solution A $(100 \mathrm{mM}$ glucose, 50mM Tris Hydrochloride (PH 8.0), 10M EDTA) containing $10 \mathrm{mg}$ of lysozyme per $\mathrm{ml}$ and incubate for 30 minutes at $37^{\circ} \mathrm{C}$. The freshly prepared $1 \%$ sodium dodecyl sulphate $(400 \mu \mathrm{l})$ in $0.2 \mathrm{~N} \mathrm{NaOH}$ was added and mixed by inverting tubes. A $30 \%$ potassium acetate solution $(300 \mu \mathrm{l})$ was added, mixed by vortexing and incubated on ice for 5 minutes and centrifuged at $5000 \mathrm{rpm}$ for 5 minutes. The supernatant was discarded and cells were extracted once with a phenol-chloroform mixture (1:1). Plasmid DNA was precipitated with absolute ethanol and $70 \%$ ethanol and 
spinned repeatedly thrice. The tubes were opened and allowed to dry in an incubator. Plasmid DNA was dissolved with Trisacetic EDTA buffer [15].

\subsubsection{Agarose Gel Electrophoresis}

Agarose powder of $0.8 \mathrm{~g}$ was weighed and boiled in 100 mls of $0.5 x$ TBE buffer (Trace Borate ethylene diamine tetraacetic acid) until the solution became a clear gel. The agarose solution was allowed to cool to about $60^{\circ} \mathrm{C}$ and $10 \mu \mathrm{l}$ of ethidium bromide was added and mixed by swirling gently. It was then poured into electrophoresis tank containing the gel buffer with the comb in place to obtain a gel thickness of about $5 \mathrm{~mm}$. The comb was then removed and $10 \mu \mathrm{l}$ of the sample was mixed with $1 \mu l$ of the loading dye and carefully loaded into each of the wells. The electrodes were connected to the power pack in such a way that the negative terminal was at the end where the sample has been loaded. The electrophoresis was allowed to run at $60-100 \mathrm{~V}$ until the loading dye has migrated about three- quarter of the electrodes. Electrodes are turned off and disconnected. The gel was observed on a UV- trans-illuminator [16].

\subsection{Molecular Analysis}

The molecular analysis for this study was carried out at International Institute of Tropical Agriculture (IITA) Ibadan. Bacteria genomic DNA was extracted from isolates using Qiagen DNA mini kit. (250) Cat No 51306 and was characterized using 16S rRNA gene sequencing methods such as: Polymerase Chain Reaction, Agarose gel electrophoresis, Sequencing and BLAST.

\subsubsection{Bacterial Genomic DNA Extraction}

Single colonies grown on medium were transferred to 1.5 $\mathrm{ml}$ of liquid medium and cultures were grown on a shaker for $48 \mathrm{~h}$ at $28{ }^{\circ} \mathrm{C}$. After this period, cultures were centrifuged at $4600 \mathrm{x}$ g for $5 \mathrm{~min}$. The resulting pellets were re-suspended in $520 \mu \mathrm{l}$ of TE buffer (10 mM Tris-HCl, 1 mM EDTA, pH 8.0). Fifteen micro litres of $20 \%$ SDS and $3 \mu \mathrm{l}$ of Proteinase K (20 $\mathrm{mg} / \mathrm{ml}$ ) were added. The mixture was incubated for 1 hour at $37^{\circ} \mathrm{C}$, then $100 \mu \mathrm{l}$ of $5 \mathrm{M} \mathrm{NaCl}$ and $80 \mu \mathrm{l}$ of a $10 \%$ CTAB solution in $0.7 \mathrm{M} \mathrm{NaCl}$ were added and mixed. The suspension was incubated for $10 \mathrm{~min}$ at $65^{\circ} \mathrm{C}$ and kept on ice for $15 \mathrm{~min}$. An equal volume of chloroform: isoamyl alcohol (24:1) was added, followed by incubation on ice for $5 \mathrm{~min}$ and centrifugation at $7200 \mathrm{x}$ g for $20 \mathrm{~min}$. The aqueous phase was transferred to a new tube, isopropanol (1:0.6) was added and DNA was precipitated at $-20{ }^{\circ} \mathrm{C}$ for $16 \mathrm{~h}$. DNA was collected by centrifugation at $7200 \mathrm{x}$ g for $10 \mathrm{~min}$, washed with $500 \mu \mathrm{l}$ of $70 \%$ ethanol, air-dried at room temperature for approximately three hours and finally dissolved in $50 \mu \mathrm{l}$ of TE buffer [17].

\subsubsection{Polymerase Chain Reaction}

PCR reaction cocktail consisted of $10 \mu \mathrm{l}$ of $5 \mathrm{x}$ GoTaq colorless reaction, $3 \mu \mathrm{l}$ of $\mathrm{MgCl} 2,1 \mu \mathrm{l}$ of $10 \mathrm{mM}$ of dNTPs mix, $1 \mu$ of 10 pmol each 27F 5'-AGA GTT TGA TCM TGG CTC AG-3' and - 1525R, 5'AAGGAGGTGATCCAGCC-3' primers and 0.3units of Taq
DNA polymerase (Promega, USA) made up to $42 \mu \mathrm{l}$ with sterile distilled water, $8 \mu \mathrm{l}$ DNA template. PCR was carried out in a Gene Amp 9700 PCR System Thermal cycler (Applied Bio system Inc., USA) PCR profile at initial denaturation, $94^{\circ} \mathrm{C}$ for $5 \mathrm{~min} ; 30$ cycles, of $94^{\circ} \mathrm{C}$ for $30 \mathrm{~s}$, $50^{\circ} \mathrm{C}$ for $60 \mathrm{~s}$ and $72^{\circ} \mathrm{C}$ for 1 minute 30 seconds; and a final extension at $72^{\circ} \mathrm{C}$ for 10 minutes, and chill at $4^{\circ} \mathrm{C}$.

\subsubsection{Purification of Amplified Product}

The PCR amplicons were ethanol purified in order to remove the PCR reagents. Briefly, $7.6 \mu \mathrm{l}$ of Na acetate $3 \mathrm{M}$ and $240 \mu \mathrm{l}$ of $95 \%$ ethanol were added to each about $40 \mu \mathrm{l}$ PCR amplified product in a new sterile $1.5 \mu \mathrm{l}$ tube eppendorf, mix thoroughly by vortexing and kept at $-20^{\circ} \mathrm{C}$ for at least $30 \mathrm{~min}$. Centrifugation was for $10 \mathrm{~min}$ at $13000 \mathrm{~g}$ and $4^{\circ} \mathrm{C}$ followed by removal of supernatant (invert tube on trash once) after which the pellet were washed by adding 150 $\mu 1$ of $70 \%$ ethanol and mixed, then centrifuged for $15 \mathrm{~min}$ at $7500 \mathrm{~g}$ and $4^{\circ} \mathrm{C}$. Again all supernatant was removed (invert tube on trash) and invert tube on paper tissue and left to dry in the fume hood at room temperature for 10-15 min It was then re-suspended with $20 \mu \mathrm{l}$ of sterile distilled water and kept in $-20^{\circ} \mathrm{C}$ prior to sequencing. The purified fragment was checked on a $1.5 \%$ Agarose gel ran on a voltage of $110 \mathrm{~V}$ for about $1 \mathrm{hr}$, to confirm the quality of the purified PCR product.

\subsubsection{Quantity and Quality Check}

Quantity of the amplified product was checked on a Nanodrop of model 2000 from thermo scientific to quantify the concentration of the amplified product and also determine purity by measuring at $260 / 280 \mathrm{~nm}$ amount of proteins left in the DNA extract.

\subsubsection{Agarose Gel Electrophoresis}

Agarose powder of $0.8 \mathrm{~g}$ was weighed and boiled in 100 $\mathrm{ml}$ of $0.5 \mathrm{x}$ TBE buffer (Trace Borate ethylene diamine tetra acetic acid) until the solution became a clear gel. The agarose solution was allowed to cool to about $60^{\circ} \mathrm{C}$ and $10 \mu 1$ of ethidium bromide was added and mixed by swirling gently. It was then poured into electrophoresis tank containing the gel buffer with the comb in place to obtain a gel thickness of about $5 \mathrm{~mm}$. The comb was then removed and $10 \mu 1$ of the sample was mixed with $1 \mu \mathrm{l}$ of the loading dye and carefully loaded into each of the wells. The electrodes were connected to the power pack in such a way that the negative terminal was at the end where the sample has been loaded. The electrophoresis was allowed to run at $60-100 \mathrm{~V}$ until the loading dye has migrated about three- quarter of the electrodes. Electrodes are turned off and disconnected. The gel was observed on a UV- trans-illuminator [16].

\subsubsection{Sequence Editing and Database Matching}

The amplified fragments were sequenced using a Genetic Analyzer 3130xl sequencer from Applied Bio-systems using manufacturers' manual while the sequencing kit used was that of Big Dye terminator v3.1 cycle sequencing kit. Bidirectional sequences obtained with forward and reverse primers were edited and aligned to generate a consensus 
sequence using Bio Edit sequence Alignment Editor (version 7.1.9). Consensus sequences were then aligned with sequences deposited in the National Centre for Biotechnological Information (NCBI) gene bank by using the Basic Local Alignment search Tool (BLAST) to establish identities of the bacteria isolates [18].

\subsection{Data Analysis}

Data was analyzed using Statistical Package for Social Sciences (SPSS) version 17.0 for windows (SPSS, Chicago IL and USA) into simple percentiles and test for significance. The level of significance was considered as $\mathrm{P}<0.05$.

\section{Results}

\subsection{Percentage Antimicrobial Susceptibleness Profile}

Table 1 depicts the percentage antimicrobial susceptibility profile of somatic antigenic positive Shigella strains $(\mathrm{N}=10)$, in which Five (5) isolates were confirmed to be S. flexneri, three (3) were given to be $S$. boydii and two (2) were $S$. sonnei. The antibiotic susceptibility revealed that the 10 Shigella isolates tested shows resistance to one or more antibiotics used. Resistance was seen to be higher in Augmentin, Nitrofurantoin and Amoxycillin at $100 \%$, followed by Tetracycline and Cotrimoxazole at $90 \%$ resistance and 10\% intermediate, with Gentamycin having $80 \%$ resistance. Susceptibility was seen to be higher in Ofloxacin, Pefloxacin and Ciprofloxacin at 80\%.

Table 2 shows the Somatic Antigenic positive and negative Shigella strains in different age groups among the pupils. Out of 32 pupils studied in the Age group of 2-4, only $2(20 \%)$ was positive for Shigella spp, while the remaining 30 was negative. Out of 82 pupils studied in the Age group of 5-7, 4 (40\%) was positive for Shigella spp, while the remaining 78 was negative. Out of 80 pupils studied in the Age group of 8 $10,3(30 \%)$ was positive for Shigella spp, while the remaining 77 was negative. Out of 54 pupils studied in the Age group of 10 and above, only $1(10 \%)$ was positive for Shigella spp while the remaining 53 was negative. Age group 5-7 accounts for the highest percentage of positive Shigella $\operatorname{spp}(40 \%)$.

\subsection{Plasmid Profiling and Molecular Identification}

Table 3 shows the Molecular identification of Shigella isolates after the generated consensus sequences which was subjected to BLAST on the NCBI Database. Figure 1 shows the agarose gel electrophoretic picture of the plasmid profile analysis of the resistant Shigella isolates. Six of the isolates possessed plasmid bands while two had no plasmid bands. Isolate A possessed double plasmid bands at $1171 \mathrm{bp}$ and $1012 \mathrm{bp}$, isolate E at 436bp and 936bp and isolate F at 436bp and $1012 \mathrm{bp}$ respectively. Isolates $\mathrm{C}, \mathrm{D}$ and $\mathrm{G}$ possessed single plasmid bands at $1171 \mathrm{bp}, 1012 \mathrm{bp}$ and $946 \mathrm{bp}$ respectively. Isolates $\mathrm{B}$ and $\mathrm{H}$ possessed no plasmid bands. Lane $\mathrm{M}$ is the marker size.
Table 1. Percentage antimicrobial susceptibility profile of somatic antigenic positive Shigella strains $(N=10)$.

\begin{tabular}{llll}
\hline Antibiotics & Susceptibility & Intermediate & Resistant \\
\hline & Number (\%) & Number (\%) & Number (\%) \\
\hline Augmentin & $0(0.0)$ & $0(0.0)$ & $10(100)$ \\
Ceftriaxone & $3(30.0)$ & $0(0.0)$ & $7(70.0)$ \\
Nitrofurantoin & $0(0.0)$ & $0(0.0)$ & $10(100)$ \\
Gentamycin & $0(0.0)$ & $2(20.0)$ & $8(80.0)$ \\
Cotrimoxazole & $0(0.0)$ & $1(10.0)$ & $9(90.0)$ \\
Ofloxacin & $8(80.0)$ & $1(10.0)$ & $1(10.0)$ \\
Amoxicillin & $0(0.0)$ & $0(0.0)$ & $10(100)$ \\
Ciprofloxacin & $8(80.0)$ & $1(10.0)$ & $1(10.0)$ \\
Tetracycline & $1(10.0)$ & $0(0.0)$ & $9(90.0)$ \\
Pefloxacin & $8(80.0)$ & $1(10.0)$ & $1(10.0)$ \\
\hline
\end{tabular}

Table 2. Somatic Antigenic positive and negative Shigella species in different age group among the pupils.

\begin{tabular}{lllll}
\hline \multirow{2}{*}{$\begin{array}{l}\text { Age } \\
\text { group }\end{array}$} & \multicolumn{2}{l}{$\begin{array}{l}\text { Somatic antigenic positive } \\
\text { Shigella }\end{array}$} & $\begin{array}{l}\text { Somatic antigenic negative } \\
\text { Shigella }\end{array}$ \\
\cline { 2 - 5 } & Number N & Percentage $\%$ & Number N & Percentage \% \\
\hline $2-4$ & 2 & 20 & 30 & 12.6 \\
$5-7$ & 4 & 40 & 78 & 32.8 \\
$8-10$ & 3 & 30 & 77 & 32.3 \\
10 and & 1 & 10 & 53 & 22.3 \\
above & & 100 & 238 & 100 \\
Total & 10 & & & \\
\hline
\end{tabular}

$\mathrm{P}>0.05$

Table 3. Molecular characterization of Shigella serotypes found among the pupils.

\begin{tabular}{|c|c|c|c|c|}
\hline Source & $\begin{array}{l}\text { Nucleotide } \\
\text { base number }\end{array}$ & $\begin{array}{l}\text { Gene Accession } \\
\text { number }\end{array}$ & $\begin{array}{l}\text { Percentage I } \\
\text { Identity }\end{array}$ & $\begin{array}{l}\text { Genomic } \\
\text { identity }\end{array}$ \\
\hline Faecal & 1787 & KJ806411.1 & $91 \%$ & $\begin{array}{l}\text { Shigella sonnei } \\
\text { strain } \mathrm{M}-\mathrm{X} 2 \mathrm{D}\end{array}$ \\
\hline Faecal & 963 & KJ620888.1 & $80 \%$ & $\begin{array}{l}\text { Shigella boydii } \\
\text { strain MHW4.1 }\end{array}$ \\
\hline Faecal & 1518 & AY696681.1 & $89 \%$ & $\begin{array}{l}\text { Shigella boydii } \\
\text { strain } 3052-94\end{array}$ \\
\hline
\end{tabular}

Genomic characterization reveals the isolates belonging to Shigella sonnei strain M-X2D, Shigella boydii strain MHW4.1 and Shigella boydii strain 3052-94.

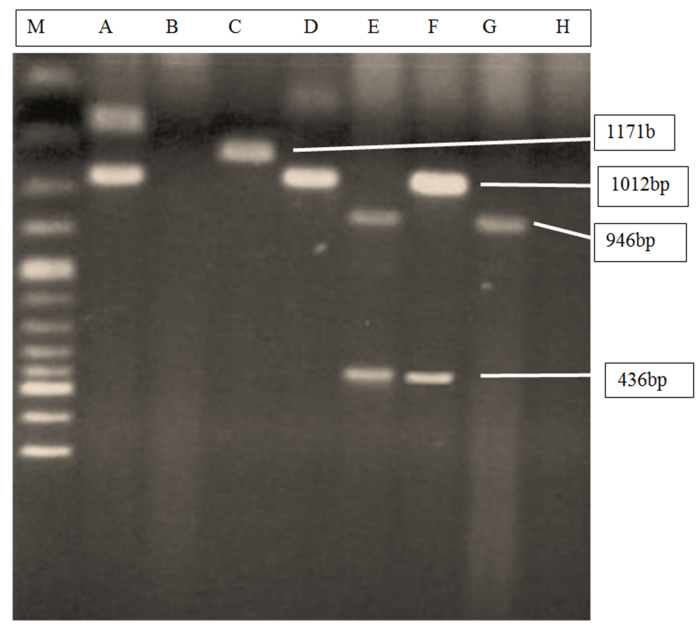

Figure 1. Agarose gel (1.0\%) electrophoresis of plasmid DNA isolated from resistant Shigella isolates. 


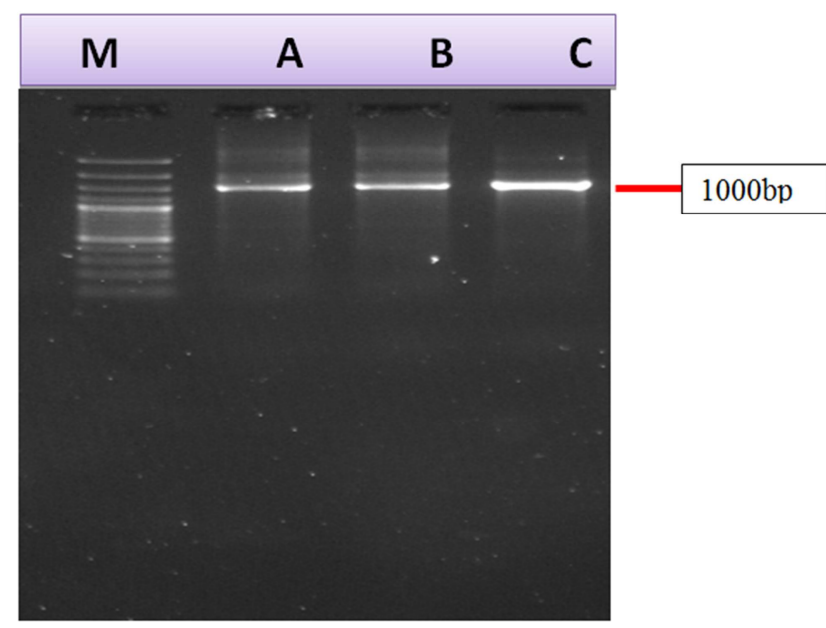

Figure 2. The gel picture of electrophoresis used in separation of the amplified PCR products.

\section{Discussion}

There were detectable plasmids in six $(75 \%)$ of the eight multi - drug resistant Shigella isolates while two (25\%) had no plasmid bands. Plasmid mediated resistance to various antimicrobial drugs have been demonstrated by various works including Isawumi et al., [19] in Ile-Ife, Ocean et al., [20] in Ayingba, Kogi state, Pazhani et al., [21, 22] in India, Ranjbar et al., [23] in Iran. Plasmids have been found to confer drug resistance to their host bacteria by various mating processes such as conjugation, transduction and transformation [24]. The plasmids obtained from the Shigella isolates had plasmid weight ranging from $436 \mathrm{bp}$ to $23.13 \mathrm{bp}$. These plasmids weights were similar to plasmids reported in Ile-Ife, Osun state, Nigeria by Isawumi et al, [19] and Ocean et al, [20] in Ayingba, Kogi state.

The inability to detect plasmids in some of the isolates may be evident that some of the multi-drug resistance observed in this research, is not only being induced by plasmids but by some external factor as evidenced by the percentage antimicrobial susceptibleness profile. Genomic characterization revealed the isolates belonging to Shigella sonnei strain M-X2D, Shigella flexneri strain MHW4.1 and Shigella boydii strain 3052-94. This study confirmed the emergence of multidrug resistant R-plasmids among Shigella spp causing diarrhoea amongst school children in Abeokuta environs, Nigeria.

\section{Conclusion}

This study highlighted the emergence of multidrug resistant R-plasmids among Shigella spp causing diarrhoea in Selected Communities in Odeda Local Government; Abeokuta, Southwestern Nigeria. The uncontrolled use of antibiotics has contributed largely to this situation. Thus government should make considerable effort to establish an antibiotic policy for the country. It is therefore recommended that extending mandatory surveillance to include shigellosis not only at hospitals but in the community to gain a better understanding of plasmids mediated resistance Shigella spp be carried out. Monitoring of plasmids mediated resistance and antimicrobial susceptibility testing was necessary to avoid treatment failure in patients with diarrhoea.

\section{Conflict of Interest}

The authors declare that they have no competing interests.

\section{References}

[1] Sansonetti, P. J. "War and peace at mucosal surfaces". Nature Review Immunology. 2005; 4: 953-964.

[2] Liu, L., Johnson, H. L., Cousens, S., Perin, J. and Scott S. Global, regional, and national causes of child mortality: an updated systematic analysis for 2010 with time trends since 2000. Lancet, 2012; 379: 2151-2161.

[3] Fischer-Walker, C. L., Rudan, I., Liu, L., Nair, H. and Theodoratos, E. Global burden of childhood pneumonia and diarrhoea. Lancet, 2013; 381: 1405-1416.

[4] UNICEF/WHO. Diarrhoea: Why children are still dying and what can be done. A Joint Publication of the United Nations Children's Fund (UNICEF) and the World Health Organization (WHO). 2009; pp. 1-40.

[5] Peter A. K., Umar U. Combating diarrhoea in Nigeria: the way forward. Journal of Microbiology and Experimentation. 2018; 6 (4): 191-197. DOI: 10.15406/jmen.2018.06.00213.

[6] CDC-Centers for Disease Control and Prevention 2002. Shigella. Annual summary. US Department of Health and Human Services: Atlanta, GA, USA.

[7] Centers for Disease Control and Prevention 2009. "Antibiotic Resistance Question and Answers". Get Smart: Know When Antibiotics Work. Retrieved 20 March 2013 Primer for Physicians. Morbidity and Mortality Weekly Report, 50 (RR02): 1-69.

[8] Centers for Disease Control and Prevention (CDC) 2013. Antibiotic resistance threats in the United States. Available at www.cdc.gov/drugresistance/threat-report2013/pdf/ar-threats2013-508.pdf.

[9] McEwen, S. A. and Fedorka-Cray, P. Antimicrobial use and resistance in animals. Journal of Infectious Diseases. 2002; 34: 93-106, 578-84.

[10] Egah, D. Z., Banwat, E. B., Audu, E. S., Allanana, J. A., Danung, M. L., Damen, J. G and Badung, B. P. "Multiple drug resistant strains of Shigella isolated in Jos, central Nigeria". Nigeria Postgraduate Medical Journal, 2003; 10: 154- 156.

[11] Farshad, S., Sheikhi, R., Japoni, A. "Characterization of Shigella strains in Iran by plasmid profile analysis and PCR amplification of Ipa genes". Journal of Clinical Microbiology, 2006; 44 (8): 2879-83.

[12] Fawole, M. O., and Oso, B. A. Laboratory Manual of Microbiology. Spectrum Book, Ibadan, Nigeria. 1998; pp 155 .

[13] Cheesbrough, M. District Laboratory Practice in Tropical Countries: Part one (Second edition). Cambridge University Press, U. K. 2006; pp 143-157. 
[14] Clinical and Laboratory Standards Institute. 2007 Performance Standards for Antimicrobial Susceptibility Testing; $16^{\text {th }}$ Information Supplement. Clinical and Laboratory Standards Institute, 2007; Wayne, P. A.

[15] Oleghe, P., Odumegwu, D., Udofia, E. and Esimore, C. Multidrug resistant bacteria isolates recovered from herbal medicinal preparations in South Eastern setting, Nigeria. International Journal of Rural and Tropical Public Health, 2011; 10: 70-75.

[16] Adeleke, M. A., Akatah, H. A., Hassan, A. O. and Adebimpe, W. O. Microbial Load and Multi drug resistance in Pathogenic Bacteria isolated from Feaces and Body surface of Cockroaches in an Urban area of South western Nigeria. Journal of Microbiology, Biotechnology and Food Sciences, 2012; 1 (6): 1448-1461.

[17] Trindade, L. C., Marques, E., Lopes, D. B., Ferreira, M. A. S. V. Development of a Molecular method for Detection and Identification of Xanthomonas campestris pv. Viticola. Summa Phytopathologica, 2007; 33 (1): 16-23.

[18] NCBI http://www.ncbi.nlm.nih.gov/BLAST

[19] Isawumi Abiola, Oluduro Anthonia Olufunke, Moses Ikechukwu Benjamin and Ariyo Adenike Bosede. Phenotypic Identification and Molecular Characterization of Shigella spp from Diarrhoeal Patients' Stool Samples in Nigeria. Nature Science, 2014; 12 (10): 169-175).
[20] Ocean, Helen Ojomachenwu, Emmanuel Aniebonam Eze, Chibuzor Nwadibe Eze and Matthew Chekwube Enebe. Drug resistance pattern of Salmonella and Shigella species isolated from selected hospitals in Anyigba, Kogi State, Nigeria. African Journal of Microbiology Research, 2015; Vol. 9 (37): 2023-2036.

[21] Pazhani, G. P., Ramamurthy, T., Mitra, U., Bhattacharya, S. K and Niyogi, S. K. Species diversity and antimicrobial resistance of Shigella spp. isolated between 2001 and 2004 from hospitalized children with diarrhoea in Kolkata (Calcutta), India. Epidemiology of Infection, 2005; 133: 10891095.

[22] Pazhani, G. P., Sarkar, B., Ramamurthy T., Bhattacharya S. K., Takeda Y and Niyogi S. K. Clonal multidrug-resistant Shigella dysenteriae type 1 strains associated with epidemic and sporadic dysenteries in eastern India. Antimicrobial Agents Chemotherapy. 2004; 48: 681-684.

[23] Ranjbar, Reza, Mohammad, Reza Pourshafie, Mohammad, Mahdi Soltan-Dallal, Mohammad Rahbar, Shohreh Farshad, Nima Parvaneh, Afra Khosravi. Fatality due to shigellosis with special reference to molecular analysis of Shigella sonnei strains isolated from the fatal cases. Iranian Journal of Clinical Infectious Disease, 2010; 5 (1): 36-39.

[24] Srhidar R. P. N. Plasmid encoded antibiotic resistance: acquisition and transfer of antibiotic resistance genes in bacteria at British Journal of Pharmacology, 2012; 153: S347-357. 